\title{
ARTICLE
}

\section{Food resources of Eucinostomus (Perciformes: Gerreidae) in a hyperhaline lagoon: Yucatan Peninsula, Mexico}

\author{
Recursos alimenticios de Eucinostomus (Perciformes: Gerreidae) en \\ una laguna hiperhalina: Península de Yucatán, México
}

\section{Ariel Adriano Chi-Espínola ${ }^{1 *}$ and María Eugenia Vega-Cendejas ${ }^{1 * *}$}

\begin{abstract}
'Laboratorio de Taxonomía y Ecología de Peces, CINVESTAV-IPN, Unidad Mérida, km 6 antigua carretera a Progreso, AP 73 Cordemex, C. P. 97310 Mérida, Yucatán, México. *kain_ex@ hotmail.com,**maruvega@mda.cinvestav.mx

Resumen.- La alta salinidad de las lagunas hiperhalinas las convierte en hábitats extremos para los organismos acuáticos, poniendo presión sobre sus adaptaciones fisiológicas especiales. Gerreidae es una familia de peces de amplia distribución y abundancia en las lagunas costeras, muy importantes para la función del ecosistema y las pesquerías. El objetivo de este estudio fue evaluar y comparar la ecología trófica de 2 especies de mojarra en la laguna hiperhalina (> 50) de Ría Lagartos, Yucatán, para proporcionar evidencia sobre la importancia de este hábitat sobre su crecimiento y requerimientos tróficos. Las muestras fueron colectadas bimensualmente durante un ciclo anual (2004-2005). Un total de 920 ejemplares de Eucinostomus argenteus (493) y E. gula (427) fueron colectados. Los componentes tróficos fueron analizados usando el Índice de Importancia Relativa (IIR) y análisis multivariados. Las mojarras fueron definidas como consumidores de segundo orden, alimentándose de anélidos, microcrustáceos (anfípodos, copépodos, tanaidáceos, ostrácodos) y cantidades significantes de detritus con variaciones en proporción y frecuencia de acuerdo a la disponibilidad del alimento. Ambas especies compartieron los mismos recursos alimenticios, sin embargo se observaron diferencias ontogenéticas con variaciones espaciales y temporales, que con ello se evita la competencia interespecífica. Los resultados proporcionan evidencia sobre la importancia de estos hábitats costeros durante las etapas del ciclo de vida y los requerimientos tróficos de estos peces juveniles marinos-eurihalinos.
\end{abstract}

Palabras clave: Sistemas lagunares hiperhalinos, mojarras, preferencias alimenticias, cambios ontogenéticos, presas bénticas

\begin{abstract}
The high salinity of hyperhaline lagoons makes them extreme habitats for aquatic organisms, putting demands on their special physiological adaptations. The Gerreidae are a family of widely distributed and abundant fish in coastal lagoons, which are very important for ecosistem functions and fisheries. The aim of this study was to evaluate and compare the trophic ecology of 2 species of mojarra in the hyperhaline lagoon ( $>50$ ) of Ria Lagartos, Yucatan, in order to provide evidence of the importance of this habitat for growth and trophic requirements. Samples were collected bimonthly during an annual cycle (2004-2005). A total of 920 fish specimens of Eucinostomus argenteus (493) and E. gula (427) were collected. Trophic components were analysed using the Relative Importance Index (RII) and multivariate analyses. The mojarras were defined as second-order consumers, feeding on annelids, microcrustaceans (amphipods, copepods, tanaidaceans, ostracods), and significant amounts of detritus with variations in proportion and frequency according to food availability. Both species shared the same food resources, however ontogenetic differences were observed with spatial and temporal variations, thus avoiding interspecific competition. Results provide evidence of the importance of these coastal habitats in the life-history stages for species and food resource requirements of juvenile marine euryhaline fish.
\end{abstract}

Key words: Hyperhaline lagunar systems, mojarras, feeding preferences, ontogenetic shifts, benthic preys

\section{INTRODUCTION}

Hyperhaline coastal lagoons are aquatic systems where freshwater discharges are extremely limited and salinity forms a gradient that increases inwards (Labonne et al. 2009). This is the case of Ria Lagartos, Yucatan, where the salinity exceeds 100 in certain areas (Valdés \& Real 2004), making it a determining factor for species distribution (Chaves \& Robert 2001, Denadai et al. 2012). Therefore, these organisms have developed osmoregulatory adaptations in order to take advantage of the hyperhaline conditions (Legendre \& Ecoutin 1989, Duponchelle \& Panfili 1998).
Fishes of the Gerreidae family are abundant and widespread in tropical coastal lagoons (Gning et al. 2010, Denadai et al. 2012, Pontes-Franco et al. 2012); as a result of this, they are considered a good study model for analysis of spatial and temporal dynamics in estuarine systems (Aguirre-León \& Yáñez-Arancibia 1986, Chaves \& Robert 2001, Pontes-Franco et al. 2012). The adaptations of Gerreidae fish to the saline variability of coastal environments, allows them to take advantage of available resources, reducing interspecific competition (Pontes-Franco et al. 2012). The commercial 
importance of gerrids lies in their use as bait to support both local and artisanal fisheries (Carpenter 2002, Denadai et al. 2012), in addition to their ecological importance for the structure and function of coastal ecosystems in tropical and subtropical regions (Hofling et al. 1998, Pessanha \& Araújo 2014). Despite its ecological and economic value, information on trophic dynamics of mojarras is very limited for hyperhaline lagoons.

Ontogenetic stages of this fish species, mainly juveniles, take advantage of the oligohaline conditions and high turbidity that characterise several habitats in these environments in search of protection from predators and to find adequate food supplies for growth (Cyrus \& Blaber 1984, Gning et al. 2008).

In general, all gerrid species present similar features with a highly protusible jaw, which allows them to feed on a wide variety of benthic prey (Cyrus \& Blaber 1982, Cervigón 1993, Nelson 2006). However feeding habits and diet compositions can change within the same species due to food availability, seasonality, age and/or sex (Blaber 1997, Gning et al. 2008, Denadai et al. 2012, Pontes-Franco et al. 2012). The aim of the present study was to evaluate the spatial, temporal and ontogenetic trophic preferences of 2 species of mojarra in the hyperhaline lagoon of Ria Lagartos, Yucatan. We used stomach content analyses as a fundamental tool to provide insights into the ecological role of the species in ecosystems (Aguirre-León \& Yáñez-Arancibia 1986).

We hypothesized that the diet of Eucinostomus argenteus Baird \& Girard, 1855 and E. gula Quoy \& Gaimard, 1824 may vary depending on the sampling site, season and body size or life-history stages. This information contributes to the functional knowledge of an extreme ecosystem such as hyperhaline lagoons.

\section{MATERIALS AND METHODS}

\section{STUdy AREA}

The Ria Lagartos lagoon is located along the western coast of Yucatan state $\left(21^{\circ} 26^{\prime}-21^{\circ} 38^{\prime} \mathrm{N}, 87^{\circ} 30^{\prime}-88^{\circ} 15^{\prime} \mathrm{W}\right)$, covering an area of approximately 9,371 ha, with a width that varies from $25 \mathrm{~m}$ to $3.5 \mathrm{~km}$, a depth between $0.5-3 \mathrm{~m}$ and a length of $80 \mathrm{~km}$. The mean annual temperature is $22^{\circ} \mathrm{C}$. Regarding its geomorphology, it has 3 basins: Río Lagartos, Las Coloradas and El Cuyo (INE 1999). The system presents many substrates (sand, seagrass, mud, limestone) (Peralta-Mexueiro \& VegaCendejas 2011), and a marked salinity gradient with values in the inner zone 4-5 times higher than seawater (>100) (Valdés $\&$ Real 2004). Considering hydrologic characteristics, 5 regions were defined by Peralta-Mexueiro \& Vega-Cendejas (2011), which are: Marine, Channel, Coloradas west, Coloradas east and Cuyo. The climatic regime is represented by 3 seasons: dry (March-June), rainy (July-October), and notherlies (November-February).

\section{FIELD SAMPLING}

Six field samplings were performed (October and December 2004; February, April, June and August 2005), taking into account the 3 climatic seasons in the region (dry, rainy and northerlies). Fish were collected using a beach seine (15 $\mathrm{m} \mathrm{x}$ $1.5 \mathrm{~m}, 2.5 \mathrm{~cm}$ mesh) at 30 sites distributed throughout the lagoon (Fig. 1). The collected individuals were preserved with formaldehyde (10\%) and were subsequently placed in labelled plastic bags for transportation.

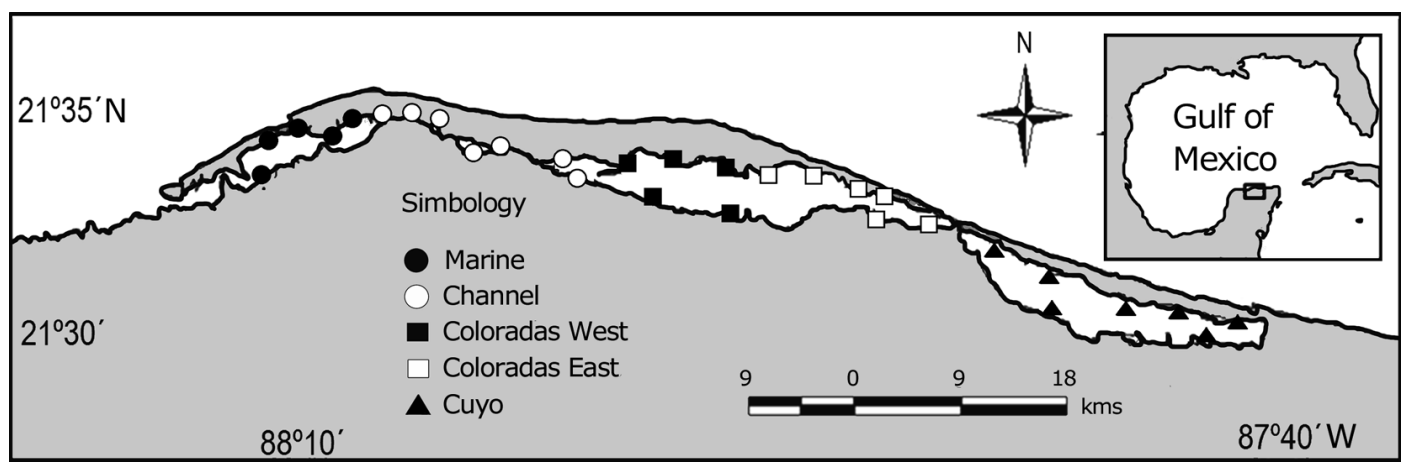

Figure 1. Study area and location of sampling zones / Área de estudio y ubicación de las zonas de muestreo 


\section{LABORATORY PROCESSING AND DATA ANALYSIS}

In the laboratory the specimens were rinsed with water and finally preserved in $70 \%$ ethanol. The fish were identified to species level using specialized keys (Castro-Aguirre et al. 1999, Carpenter 2002). Standard length and total weight were measured for all samples. The stomach content was removed and the components of their diets were identified to the lowest possible taxonomic level using specialized literature (Kudo 1976, Amos \& Amos 1985, Platt \& Warwick 1988, Ruppert \& Barnes 1996, Littler \& Littler 2000).

The diet composition was analysed using the Relative Importance Index (RII) (Pinkas et al. 1971) modified by Hyslop (1980), following the formula $\mathrm{RII}=(\% \mathrm{~A}+\% \mathrm{~W}) * \% \mathrm{FO} . \% \mathrm{~A}$ refers to the estimated percentage of the total digested area occupied by each prey item and was obtained using a millimetric grid (Poot-Salazar et al. 2005, Canto-Maza \& Vega-Cendejas 2007). The percentage of wet weight (\%W) of each diet component was obtained using an analytical balance. The frequency of ocurrence $(\% \mathrm{FO})$ was calculated from the number of times (n) that a certain prey item appeared in the stomach content of a group of fish (NE) using the equation $\mathrm{FO}=(\mathrm{n} /$ NE)*(100) (Tresierra \& Culquichicón 1995). The food was classified as preferential (FO > 50\%), secondary $(50 \%>\mathrm{FO}$ $>10 \%)$ and accidental $(\mathrm{FO}<10 \%)$ based on the values of FO (Yáñez-Arancibia 1975). For the ontogenetic analysis of the diet, Sturges' rule was used (Sturges 1926), where the fish are divided into size categories based on their standard lengths using the equation: $($ class interval $=$ maximum size-minimum size $) /\left(\mathrm{N}^{\circ}\right.$ of classes), where $\mathrm{N}^{\circ}$ of classes $=1+(3.3 \log n)$ and $(n)$ is the number of individuals.

For each species, 3 canonical correspondence analyses (CCA) (Ter Braak \& Smilauer 2002) were performed in order to correlate the prey used with the seasons, zones and size classes. In this analysis specimens from all sizes were used in order to avoid information loss. However, accidental preys items $(\% \mathrm{FO}<10 \%)$ were eliminated from the general analysis, and were included with the standard length and weight of fish as covariates in order to avoid false statistical differences. In both cases, the Monte Carlo test was performed to determine whether the variables recorded were significant (Adjeroud et al. 1998, Kupschus \& Tremain 2001). For the statistical analysis, the multivariate statistical package CANOCO v. 4.5 (Ter Braak \& Smilauer 2002) was used.

\section{ReSUltS}

\section{TROPHIC PREFERENCES}

A total of 493 specimens of Eucinostomus argenteus and 427 of E. gula were collected in Ria Lagartos during the study period. In general, the food groups consumed preferentially (FO $>50 \%$ ) by E. argenteus were the amphipods, annelids and copepods. The highest RII values were for amphipods (33\%), annelids (28\%) and detritus (12\%). E. gula preferentially consumed amphipods, annelids and detritus, and the highest RII values corresponded to the annelids group (45\%), amphipods (14\%) and detritus (11\%) (Appendix 1 and 2).

\section{SPATIAL AND TEMPORAL TROPHIC VARIATION}

In the inlet of the lagoon (Marine), E. argenteus preferentially consumes detritus and some tanaidaceans. In Coloradas west and Coloradas east regions, this species feeds on amphipods and annelids. Finally, in the inner region (Cuyo), its diet changes to insects. The diet of E. gula is heterogenous with regards to annelids throughout the lagoon; the intake of amphipods is much greater in Coloradas west and Cuyo (Fig. 2).

During the rainy and northerlies seasons, E. argenteus mostly consumed amphipods and annelids; in the dry seasons the proportions of these components in the diet decreased, and an increased consumption of detritus and tanaidacea was observed. In comparison, E. gula mainly consumed annelids during the rainy season, accounting for more than half of its diet; while other diets were similarly used with at most $10 \%$ each. In the northerlies and dry seasons, E. gula consumed annelids, detritus and tanaidaceans in higher proportions, whereas in the northerlies and in the dry season copepods and amphipods were an important component of the diet respectivelty, contributing approximately $20 \%$ each (Fig. 3).

\section{ONTOGENETIC TROPHIC VARIATION}

Using Sturges' rule, 9 size classes were identified for $E$. argenteus with intervals of $0.7 \mathrm{~cm}$ between sizes, where the number of individuals per class varied between 9 and 102. Using the same rule, 8 different size classes were identified for $E$. gula with intervals of $0.6 \mathrm{~cm}$, with a variation in the number of individuals between 8 and 126 (Table 1).

For $E$. argenteus, the most important components of the diet of the small size classes were amphipods, annelids and copepods, which together comprised more than $90 \%$ of the diet. Other prey items such as tanaidaceans, detritus and insects were of minor relevance. The middle and larger sizes classes consumed significant amounts of detritus and tanaidaceans, while the proportion of other prey items decreased, for example amphipods and annelids. In all stages of $E$. gula, annelids and amphipods form part of the diet too, although in small sizes (A and B) an important presence of copepods is observed and in the largest sizes $(\mathrm{G}$ and $\mathrm{H})$ tanaidaceans and detritus were observed (Fig. $4)$. 


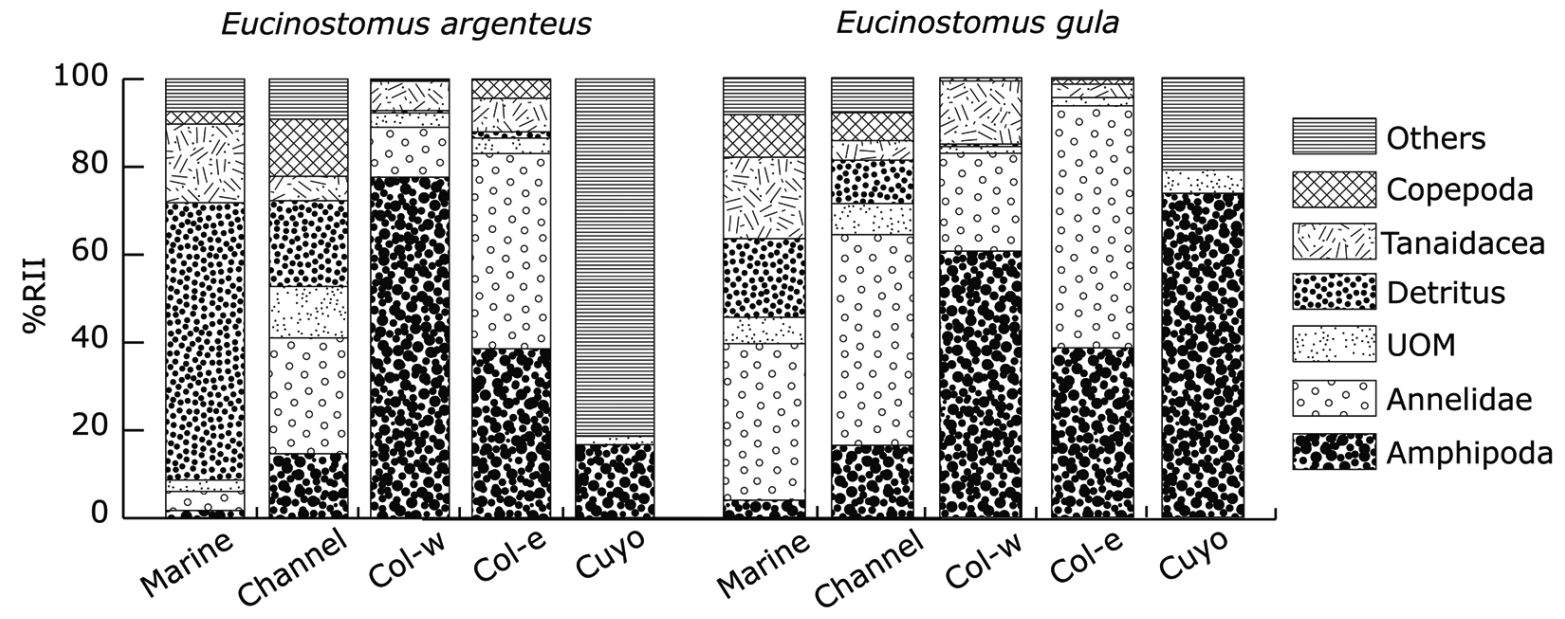

Figure 2. Variation in the trophic spectrum between zones of the Ría Lagartos lagoon system, based on the Percentaje of Relative Importance Index (\%RII), where the 'Others' category in Cuyo region corresponds to $\mathbf{9 0 \%}$ of insects / Variación en el espectro trófico entre zonas para el sistema lagunar de Ría Lagartos, en base al Porcentaje del Indice de Importancia Relativa (\%RII), donde la categoría 'Otros' en la región del Cuyo corresponde a un $90 \%$ de insectos

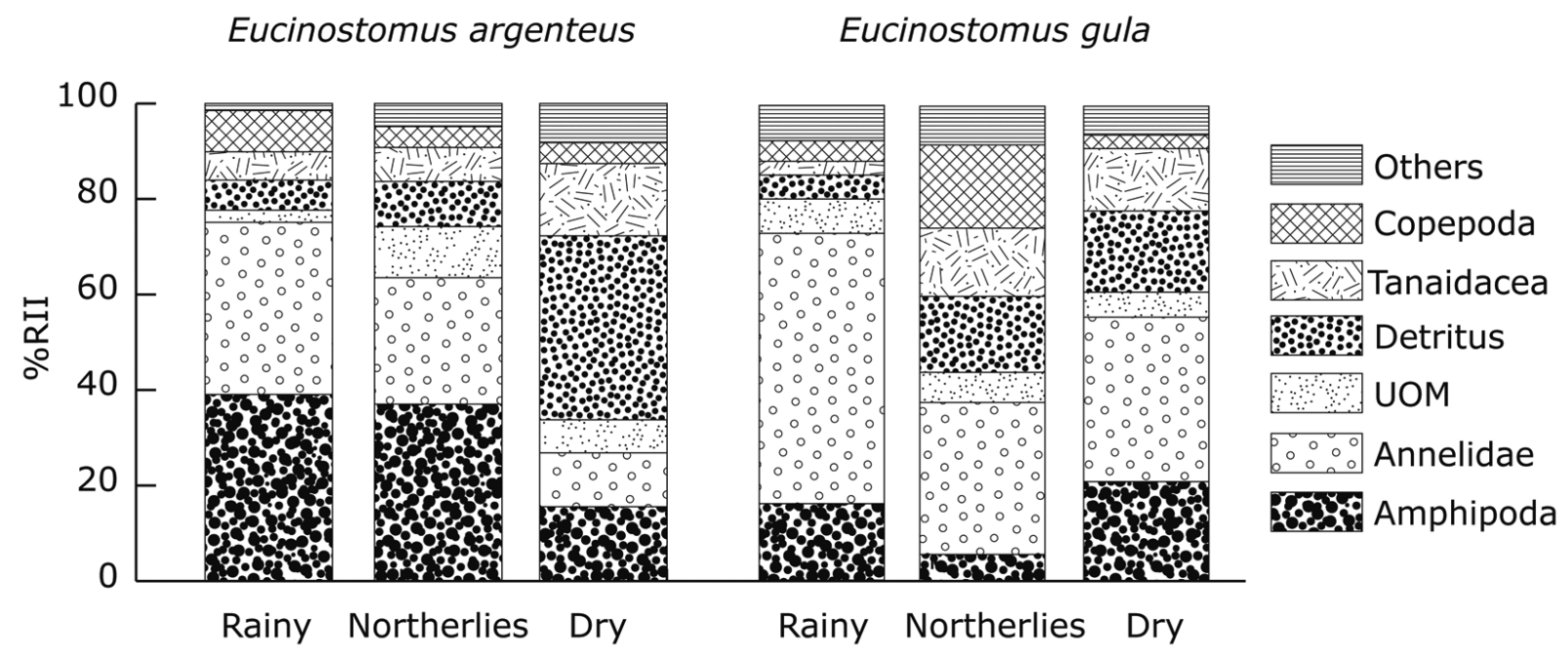

Figure 3. Variation in the trophic spectrum between seasons for the Ría Lagartos lagoon system, based on the Relative Importance Index (RII) / Variación en el espectro trófico entre temporadas para el sistema lagunar de Ría Lagartos, en base al Indice de Importancia Relativa (RII) 
A

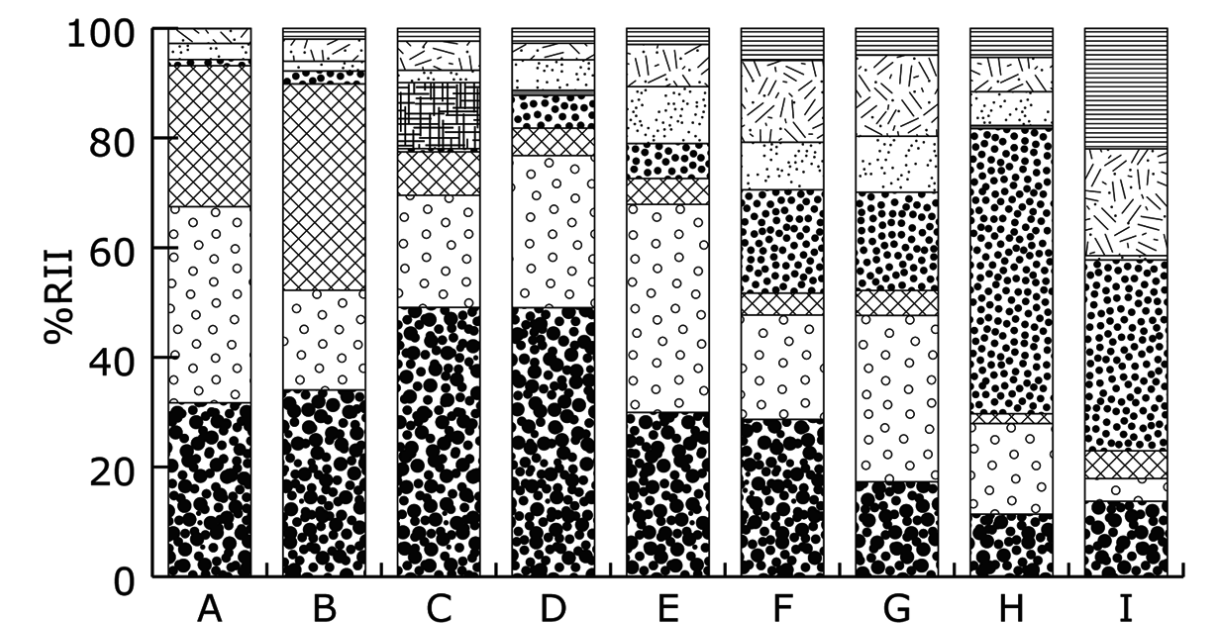

B

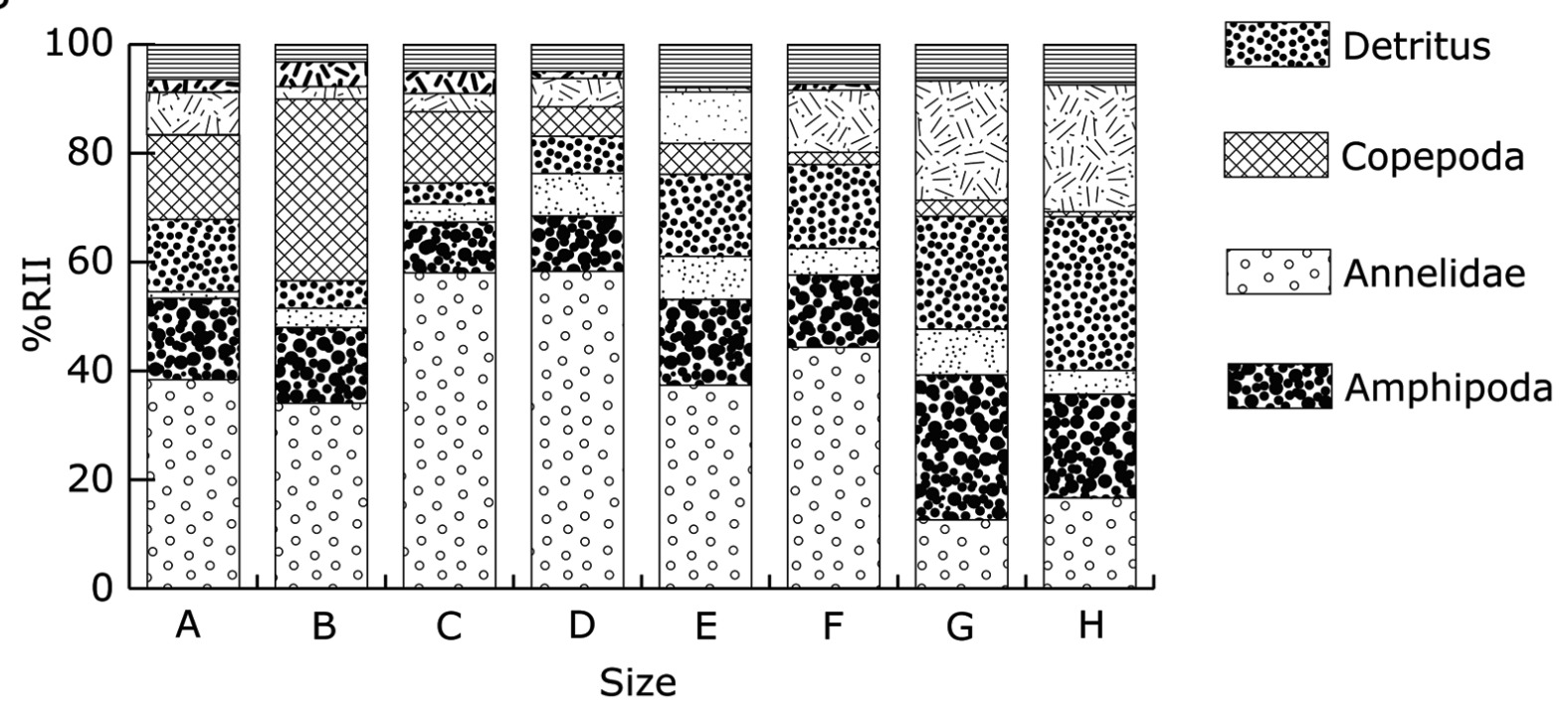

Figure 4. Variation in the trophic spectrum of $E$. argenteus between different size classes (A-I) for the Ría Lagartos lagoon system, based on the Percentage of Relative Importance Index Percentage (\%RII). A) corresponds to E. argenteus and B) E. gula / Variación en el espectro trófico de E. argenteus entre los distintos intervalos de clases (A-I) para el sistema lagunar de Ría Lagartos, en base al porcentaje del Indice de Importancia Relativa (\%RII). A) corresponde a la especie E. argenteus y B) E. gula 
Table 1. Size intervals in standard length (cm) obtained using Sturges' rule (1926), and number of specimens (N) corresponding to each class in E. argenteus (Ea) and E. gula (Eg) / Intervalo de talla en longitud estándar $(\mathrm{cm})$ obtenido mediante la regla de Sturges (1926), y número de especímenes $(\mathrm{N})$ correspondientes a cada clase en $\mathrm{E}$. argenteus (Ea) y E. gula (Eg)

\begin{tabular}{|c|c|c|c|c|}
\hline \multirow{2}{*}{ Class } & \multicolumn{2}{|c|}{ Interval } & \multicolumn{2}{|c|}{$\mathrm{N}$} \\
\hline & $\mathrm{Ea}$ & $\mathrm{Eg}$ & $\mathrm{Ea}$ & $\mathrm{Eg}$ \\
\hline A & $1.3-2.0$ & $2.5-3.1$ & 9 & 8 \\
\hline B & $2.1-2.8$ & $3.2-3.8$ & 51 & 42 \\
\hline $\mathrm{C}$ & $2.9-3.6$ & $3.9-4.5$ & 102 & 52 \\
\hline D & $3.7-4.4$ & $4.6-5.2$ & 102 & 126 \\
\hline E & $4.5-5.2$ & $5.3-5.9$ & 59 & 124 \\
\hline $\mathrm{F}$ & $5.3-6.0$ & $6.0-6.6$ & 85 & 49 \\
\hline G & $6.1-6.8$ & $6.7-7.3$ & 55 & 17 \\
\hline $\mathrm{H}$ & $6.9-7.6$ & $7.4-8.0$ & 18 & 9 \\
\hline I & $7.7-8.4$ & - & 12 & - \\
\hline
\end{tabular}

The results of the canonical correspondence analysis (CCA) indicated that the dietary components of $E$. argenteus presented significant variations at a temporal $(\mathrm{gl}=492 ; \mathrm{F}=24.07 ; P=$ 0.002), spatial $(\mathrm{gl}=492 ; \mathrm{F}=75.66 ; P=0.002)$ and ontogenetic level ( $\mathrm{gl}=492 ; \mathrm{F}=30.61 ; P=0.002)$. Similarly, E. gula presented significant temporal $(\mathrm{gl}=426 ; \mathrm{F}=11.97 ; P=0.002)$, spatial $(\mathrm{gl}=426 ; \mathrm{F}=14.16 ; P=0.002)$ and ontogenetic differences $(\mathrm{gl}=426 ; \mathrm{F}=5.48 ; P=0.020)($ Fig. 5$)$.

\section{Discussion}

Eucinostomus argenteus and E. gula in the Ria Lagartos lagoon consume a wide variety of benthic food elements (approximately 78 items), since these are sympatric species, a superimposition of food resources might be expected (Russo et al. 2008, Mariani et al. 2011). However between the 2 species, there is a resource partitioning in terms of the proportion and frequency of prey items. These changes are probably a consequence of habitat use and morphological changes in the fish (Ward-Campbell et al. 2005, Russo et al. 2008, Pereira et al. 2014), which results in a wide trophic spectrum (generalist) or reduced trophic spectrum (specialist) (Hammerschlag et al. 2010). These variations are in accordance with the niche partitioning theory (Bolnick et al. 2003, Mariani et al. 2011), which states that every time that a species decreases food resources shared by specialization, it reduces interspecific competition, while intraspecific competition increases (Pereira et al. 2014).

The diet of E. argenteus and E. gula mainly consists of microcrustacea, including copepods and amphipods, as well as polychaetes and has been repeatedly cited in the literature (Cyrus \& Blaber 1982, Motta et al. 1995, Zahorcsak et al. 2000, Gning et al. 2010, Denadai et al. 2012). However, Kershner \& Peterson (1985) mentioned bivalves as preferential prey, which were not reflected in the present study, probably as a result of the low abundance of these in the system (KukDzul et al. 2012). Furthermore, Branco et al. (1997) and Hofling et al. (1998) highlight those algae were an important component of the diet. Nevertheless, plant fragments have been found in the stomachs of multiple species, although in reality their presence may be accidental due to the voracity with which the organisms consume their main prey (Gning et al. 2008, Nanjo et al. 2008, Nakane et al. 2011), since these species have been considered second order consumers.

In certain estuaries or coastal lagoons where freshwater discharges are limited, salinity increases towards the inner zone, forming a hyperhaline system (Labonne et al. 2009). This is the case of the Ria Lagartos coastal lagoon, where salinities exceed 100 (Valdés \& Real 2004). Since salinity is the determining factor in the distribution of fish species (Chaves \& Robert 2001, Denadai et al. 2012), they have developed very clear osmoregulatory adaptations, involving modifications in their growth or reproduction to take advantage of the hyperhaline conditions (Legendre \& Ecoutin 1989, Duponchelle \& Panfili 1998).

In the present study, E. argenteus exhibits behavior associated with euryhaline conditions (sal: 10-100) with a broad feeding spectrum along the lagoon. The presence of detritus recorded in specimens from the inlet of the lagoon (Marine zone) is related to the currents, which result in an accumulation of organic matter on the bottom (Hernández-Guevara et al. 2008). In the Channel, Coloradas west and Coloradas east regions, the specimens from this species preferentially consume amphipods and annelids in different proportions, a diet that has been observed by other authors (Branco et al. 1997, Denadai et al. 2012). However, in the region of Cuyo, there is an increased consumption of insects (Diptera and Hymenoptera), which provides an insight into the degree of connectivity between the mangroves and coastal lagoons (Odum \& Heald 1975); and demonstrates the importance of this food resource in the ecosystem's trophic web.

On the other hand, E. gula exhibits a diet with high preference for annelids in similar proportions in all regions, and a consumption of amphipods that gradually increases towards the inner region; this diet has also been reported by other authors (Kershner \& Peterson 1985, Gning et al. 2008). Since the distribution of amphipods is more related to their salinity tolerance (Gning et al. 2010), the increasing trophic preference of $E$. gula for amphipod consumption towards the inner region could be more related to the numerical abundance of these 

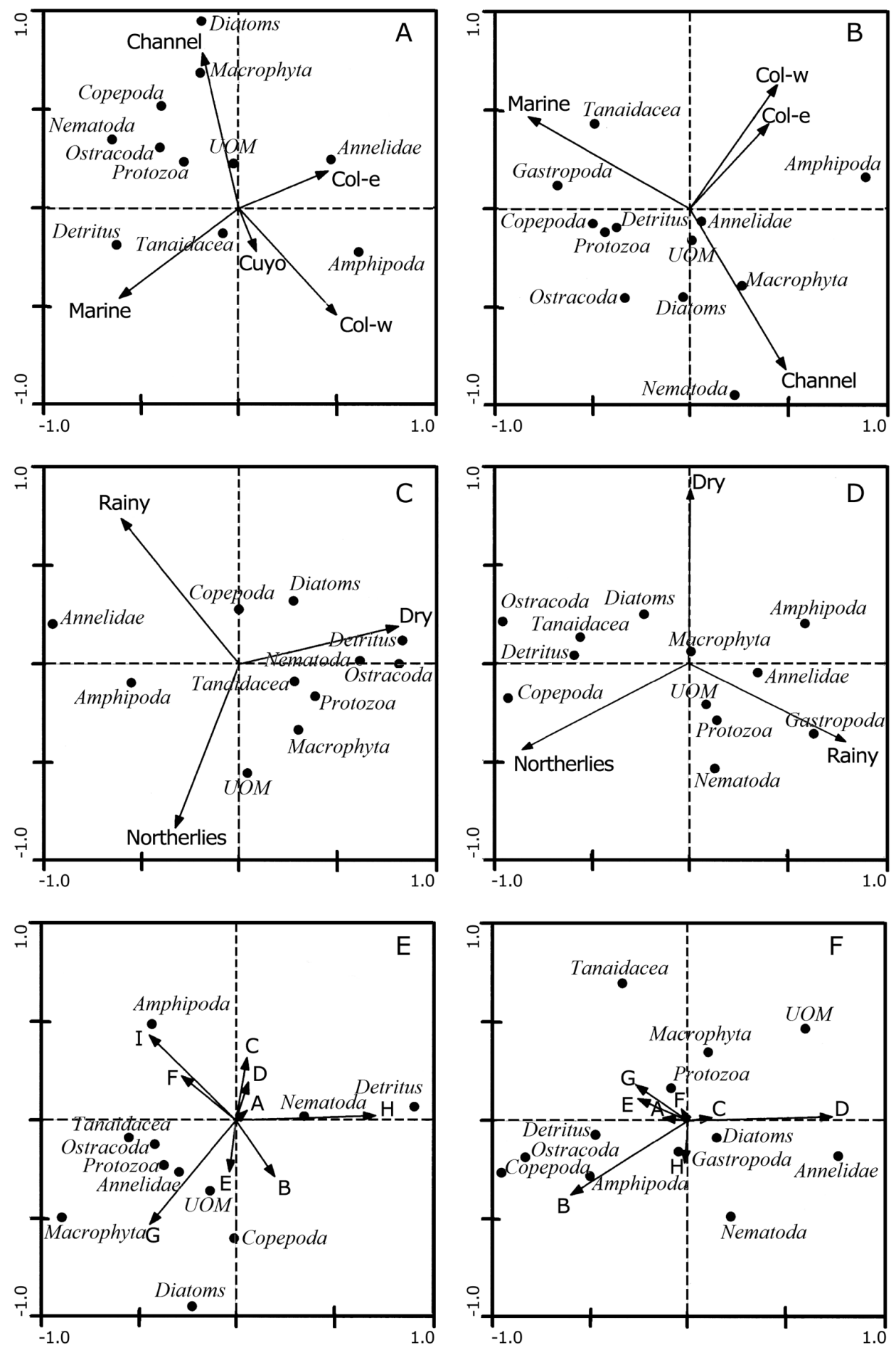

Figure 5. Ordination biplot of CCA of the proportion of food resources (preferential and secondary), using the accidental species, standard length and weight as covariables, where: A) E. argenteus (prey-zone), C) E. argenteus (prey-season), E) E. argenteus (prey-size), B) E. gula (prey-zone), D) E. gula (prey-season), F) E. gula (prey-size) / Biplot de ordenación del CCA de la proporcion de los recursos alimenticios (preferencial y secundario), usando las especies accidentales, longitud estandar y peso como covariables, donde: A) E. argenteus (presa-zona), C) E. argenteus (presa-temporada), E) E. argenteus (presa-talla), B) E. gula (presa-zona), D) E. gula (presa-temporada), F) E. gula (presa-talla) 
invertebrates in the mangroves (Kuk-Dzul et al. 2012), than to the feeding preference of the species (Cyrus \& Blaber 1992, Gning et al. 2008).

A factor that undoubtedly has a great influence on the diet of the fish is the availability of the resource in the environment. Pech et al. (2007) and Hernández-Guevara et al. (2008) mentioned that polychaetes were the most abundant benthic fauna in a lagoon system on the Yucatecan coast, primarily during the rainy season. This population decreases in northerlies and recovers during the dry season. In the rainy season there is an increase in precipitation and organic matter, and a decrease in salinity in the system (Kolm \& Andretta 2003), which results in an increase in macrophyte biomass and abundance of the resources available in them (Castro-Aguirre et al. 1999). However, there is a reduction in polychaete populations since they are sensitive to the increase in salinity (Pech et al. 2007), and tend to consume organic matter or detritus during the dry season.

It is known that the composition and distribution of the species respond seasonally to variations in hydrological factors, for example salinity, transparency, and suspended sediment (Hernández-Guevara et al. 2008). Furthermore, the grain size characteristics affect the benthic community (Beukema \& Flach 1995). These factors could lead to seasonal diet variation. During the rainy season freshwater discharges reduce salinity, which is conducive to the development of polychaetes. In northerlies wind intensity increases, inducing mixing in the water column, resulting in suspension of organic matter and turbidity (Jayaraj et al. 2007) which greatly benefits filter feeding organisms (Pech et al. 2007), including copepods and tanaidaceans and a high availability of detritus, as reflected in the diet of $E$. gula. Finally, in the dry season, evaporation increases salinity, favouring the presence of marine benthic larvae, which together with the colonization and opportunistic behaviour of organisms, contributes to increasing the species abundance of populations, just as the entrance of sea water to the lagoon contributes to the recovery of polychaete populations (Hernández-Guevara et al. 2008).

Trophic variation during growth is a common characteristic in ichthyofauna (Gning et al. 2008). In the present study, $E$. argenteus and E. gula had a similar diet, however a food resource partition was observed, where E. argenteus fed on amphipods and E. gula on annelids. This flexibility of diet, could be influenced by several factors including salinity, dissolved oxygen, temperature (Dantas et al. 2013), prey distribution (Pech et al. 2007, Kuk-Dzul et al. 2012), morphological changes such as increased mouth size (Ward-Campbell et al. 2005, Nakane et al. 2011), strengthening of the jaw and teeth, an increase in capturability (Nanjo et al. 2008, Pereira et al.
2014), or a simple change in metabolic requirements (Wootton 1998, Hammerschlag et al. 2010) where juveniles use the energy for growth and survival, while adults utilize it for reproduction and maintenance (Gning et al. 2008).

When both species of Gerrids (E. argenteus and E. gula) are small, they consume large amounts of copepods. This could be due to their vertical distribution, substrate preferences, feeding behavior or species social interaction (Van Rooij et al. 1996), where juveniles feed on water column organisms including copepods or amphipods, and adults feed on benthic ones such as annelids and crustaceans (Pereira et al. 2014). In the case of adults, their benthic feeding behavior is reflected in an important accidental ingestion of detritus (Motta et al. 1995, Gning et al. 2008, 2010).

In conclusion, E. argenteus and E. gula use the same dietary items but they differ in the proportion they consume. These changes where observed at spatial, temporal and ontogenic levels, which suggests a partitioning of resources between both species (Arenas-Granados \& Acero 1992). In this study, the mojarras were classified as benthic organism consumers, focusing mainly on annelids and amphipods, both during different life stages and across throughout different habitats and seasons, taking advantage of the availability of the most abundant resources in the lagoons, which are equally affected by the salinity gradient and temporal variations in turbidity (HernándezGuevara et al. 2008).

\section{ACKNOWLEDGEMENTS}

The authors thank Mirella Hernández de Santillana and Walter Canto Maza for their valuable cooperation, suggestions and support. We also thank to the Fish Taxonomy and Ecology Laboratory staff and finally we extended our gratitude to the anonymous group of reviewers for their valuable comments and suggestions that substantially enriched the manuscript. Fish were caught during the study as part of the project 'Contribución a la riqueza ictiofaunística de la reserva de Ría Lagartos, Yucatán' with reference $\mathrm{N}^{\circ} \mathrm{BK} 026$, funded by the CONABIO.

\section{LITERATURE CITED}

Adjeroud M, Y Letourneur, M Porcher \& B Salvat. 1998. Factors influencing spatial distribution of fish communities on a fringing reef at Mauritius, S.W. Indian Ocean. Environmental Biology Fishes 53: 169-182.

Aguirre-León A \& A Yáñez-Arancibia. 1986. Las mojarras de la Laguna de Términos, Campeche: taxonomía, biología, ecología y dinámica trófica (Pisces: Gerreidae). Anales de Instituto de Ciencias del Mar y Limnología, Universidad Nacional Autónoma de Mexico 13: 366-444. 
Amos HW \& SW Amos. 1985. Atlantic \& Gulf Coasts, 670 pp. The Audubon Society Nature Guides, New York.

Arenas-Granados A \& P Acero. 1992. Organización trófica de las mojarras (Pisces:Gerreidae) de la ciénaga Grande de Santa Marta (Caribe colombiano). Revista de Biología Tropical 40: 325-334.

Beukema JJ \& EC Flach. 1995. Factors controlling the upper and lower limits of the intertidal distribution of two Corophium species in the Wadden Sea. Marine Ecology Progress Series 125: $117-126$

Blaber SJM. 1997. Fish and fisheries of tropical estuaries, 367 pp. Chapman \& Hall, London.

Bolnick DI, R Svanback, JA Fordyce, LH Yang, JM Davis, CD Hulsey \& ML Forister. 2003. The ecology of individuals: incidence and implications of individual specialization. American Naturalist 161: 1-28.

Branco CW, T Aguiaro, FA Esteves \& EP Caramaschi. 1997. Food sources of the teleost Eucinostomus argenteus in two coastal Lagoons of Brazil. Studies on Neotropical Fauna and Environment 32: 33-40.

Canto-Maza WG \& ME Vega-Cendejas. 2007. Distribución, abundancia y preferencias alimenticias del pez sapo Opsanus phobetron (Batrachoididae) en la laguna costera de Chelem, Yucatán, México. Revista de Biología Tropical 55: 979-988.

Carpenter KE. 2002. The living marine resources of the Western Central Atlantic. Volume 3. Bony fishes part 2 (Opistognathidae to Molidae), sea turtles and marine mammals. FAO Species Identification Guide for Fishery Purposes and American Society of Ichthyologists and Herpetologists Special Publication 5: 1375-2127. FAO, Rome.

Castro-Aguirre JL, HS Espinosa-Pérez \& JJ Schmitter-Soto. 1999. Ictiofauna estuarino-lagunar y vicaria de México. Serie Biotecnologías, 711 pp. Limusa Noriega, México.

Cervigón F. 1993. Los peces marinos de Venezuela 2: 1-497. Fundación Científica los Roques, Caracas.

Chaves PT \& MC Robert. 2001. Nota complementar sobre os hábitos de Gerres melanopterus (Teleostei, Gerreidae)

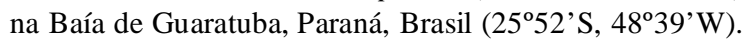
Revista Brasileira de Zoología 18: 255-259.

Cyrus DP \& SJ Blaber. 1982. Mouth part structure and function and the feeding mechanisms of Gerres (Teleostei). South African Journal of Zoology 17: 117-121.

Cyrus DP \& SJ Blaber. 1984. The feeding ecology of Gerreidae Teleostei in the Kosi system, with special reference to their seasonal diet. Lammergeyer 32: 35-49.

Dantas D, M Barletta, J de Assis-Almeida-Ramos, A Lima \& M da Costa. 2013. Seasonal diet shifts and overlap between two sympatric catfishes in an estuarine nursery. Estuaries and Coasts 36: 237-256.

Denadai MR, FB Santos, E Bessa, WS Fernandez, CC Paschoal \& A Turra. 2012. Diets of Eucinostomus argenteus (Baird \& Girard, 1855) and Diapterus rhombeus (Cuvier, 1829) (Perciformes: Gerreidae) in Caraguatatuba Bay, southeastern Brazil. Pan-American Journal of Aquatic Sciences 7: 143-155.
Duponchelle F \& J Panfili. 1998. Variations in age and size at maturity of female Nile tilapia, Oreochromis niloticus, populations from man-made lakes of Côte d'Ivoire. Environmental Biology of Fishes 52: 453-465.

Gning N, G Vidy \& OT Thiaw. 2008. Feeding ecology and ontogenic diet shifts of juvenile fish species in an inverse estuary: The Sine-Saloum, Senegal. Estuarine, Coastal and Shelf Science 76: 395-403.

Gning N, F Le Loc'h, OT Thiaw, C Aliaume \& G Vidy. 2010. Estuarine resources use by juvenile Flagfin mojarra (Eucinostomus melanopterus) in an inverse tropical estuary (Sine Saloum, Senegal). Estuarine, Coastal and Shelf Science 86: 683-691.

Hammerschlag N, D Ovando \& JE Serafy. 2010. Seasonal diet and feeding habits of juvenile fishes foraging along a subtropical marine ecotone. Aquatic Biology 9: 279-290.

Hernández-Guevara NA, D Pech \& P Ardisson. 2008. Temporal trends in benthic macrofauna composition in response to seasonal variation in a tropical coastal lagoon, Celestun, Gulf of Mexico. Marine and Freshwater Research 59: 772-779.

Hofling JC, LI Ferreira, FB Ribeiro-Neto, AM PaivaFilho, PA Lima \& TE Gibin. 1998. Alimentacao de peixes da familia Gerreidae do complexo estuarino-lagunar de Cananeia, SP, Brasil. Bioikos 12: 7-18.

Hyslop EJ. 1980. Stomach contents analysis-a review of methods and their application. Journal of Fish Biology 17:411-429.

INE. 1999. Programa de manejo Reserva de la Biosfera Ría Lagartos, México, 203 pp. Instituto Nacional de Ecología, México.

Jayaraj KA, KV Jayalakshmi \& K Saraladevi. 2007. Influence of environmental properties on macrobenthos in the northwest Indian shelf. Environmental Monitoring and Assessment 127: 459-475.

Kershner BA \& MS Peterson. 1985. Ecotopic and ontogenetic trophic variation in mojarras (Pisces:Gerreidae). Estuaries 8:311-322.

Kolm H \& L Andretta. 2003. Bacterioplancton in different tides of the Perequê tidal creek, Pontal do Sul, Paraná, Brasil. Brazilian Journal of Microbiology 34: 97-103.

Kudo RR. 1976. Protozoología, 905 pp. Compañía Editorial Continental, México.

Kuk-Dzul JG, G Gold-Bouchot \& PL Ardisson. 2012. Benthic infauna variability in relation to environmental factors and organic pollutants in tropical coastal lagoons from the northern Yucatan Peninsula. Marine Pollution Bulletin 64: 2725-2733.

Kupschus S \& D Tremain. 2001. Associations between fish assemblages and environmental factors in nearshore habitats of a subtropical estuary. Journal of Fish Biology 58: 1383-1403.

Labonne M, E Morize, P Scolan, R Lae, E Dabas \& E Bohn. 2009. Impact of salinity on early life history traits of three estuarine fish species in Senegal. Estuarine, Coastal and Shelf Science 82: 673-681. 
Legendre M \& JM Ecoutin. 1989. Suitability of brackish water tilapia species from the Ivory Coast for lagoon aquaculture I-Reproduction. Aquatic Living Resources 2: 7179 .

Littler DS \& MM Littler. 2000. Caribbean reef plants : An identification guide to the reef plants of the Caribbean, Bahamas, Florida and Gulf of Mexico, 542 pp. OffShore Graphics, Washington.

Mariani S, C Boggan \& D Balata. 2011. Food resource use in sympatric juvenile plaice and flounder in estuarine habitats. Marine Ecology 32: 96-101.

Motta PJ, KB Clifton, P Hernandez, BT Eggold, SD Giordano \& R Wilcox. 1995. Feeding relationships nine species of seagrass fishes of Tampa Bay, Florida. Bulletin of Marine Science 56: 185-200.

Nakane Y, Y Suda \& M Sano. 2011. Food habits of fishes on an exposed sandy beach at Fukiagehama, South-West Kyushu Island, Japan. Helgoland Marine Research 65: 123131.

Nanjo K, H Kohno \& M Sano. 2008. Food habits of fishes in the mangrove estuary of Urauchi River, Iriomote Island, southern Japan. Fisheries Science 74: 1024-1033.

Nelson JS. 2006. Fishes of the world, 601 pp. John Wiley and Sons, New York.

Odum WE \& EJ Heald. 1975. The detritus-based food web of an estuarine mangrove community. In: Cronin LE (ed). Estuarine research: Chemistry, biology, and the estuarine system 1: 265-286. Academic Press, New York.

Pech D, P Ardisson \& NA Hernández-Guevara. 2007. Benthic community response to habitat variation: A case of study from a natural protected area, the Celestun coastal lagoon. Continental Shelf Research 27:2523-2533.

Peralta-Meixueiro MA \& ME Vega-Cendejas. 2011. Spatial and temporal structure of fish assemblages in a hyperhaline coastal system: Ría Lagartos, Mexico. Neotropical Ichthyology 9: 673-682.

Pereira PHC, B Barros, R Zemoi \& BP Ferreira. 2014. Ontogenetic diet changes and food partitioning of Haemulon spp. coral reef fishes, with a review of the genus diet. Reviews in Fish Biology and Fisheries 25: 245-260.

Pessanha ALM \& FG Araújo. 2014. Shifts of the feeding niche along the size dimension of three juvenile fish species in a tidal mudflat in southeastern Brazil. Marine Biology 161: 543-550.

Pinkas L, MS Oliphant \& IL Iverson. 1971. Food habits of albacore, bluefin tuna, and bonito in California waters. California Department of Fish and Game, Fish Bulletin 152: 1-105.
Platt HM \& RM Warwick. 1988. Free-living marine nematodes. Part II: British chromadorids. In: Kermack DM $\&$ RS Barnes (eds). Synopses of the British Fauna (New Series): 1-502. Brill/Backhuys, Leiden.

Pontes-Franco T, L Mitrano, T Pires \& F Gerson. 2012. Patterns of spatial distribution of five species of mojarras (Actinopterygii: Gerreidae) in a small tropical estuary in southeastern Brazil. Journal of the Marine Biological Association of the United Kingdom 92: 1217-1225.

Poot-Salazar AV, WG Canto-Maza \& ME Vega-Cendejas. 2005. Habitos alimenticios de Floridichthys polyommus Hubbs, 1936 (Pisces: Cyprinodontidae) en dos sistemas lagunares costeros. Hidrobiologia 15: 183-194.

Ruppert EE \& RD Barnes. 1996. Zoología de los invertebrados, 1114 pp. McGraw-Hill-Interamericana, México.

Russo T, D Pulcini, Á O’Leary, S Cataudella \& S Mariani. 2008. Relationship between body shape and trophic niche segregation in two closely related sympatric fishes. Journal of Fish Biology 73: 809-828.

Sturges HA. 1926. The choice of a class interval. Journal of the American Statistical Association 21: 65-66.

Ter Braak CJ \& P Smilauer. 2002. CANOCO reference manual and CanoDraw for Windows user's guide: software for canonical community ordination (version 4.5), $500 \mathrm{pp}$. Microcomputer Power, New York.

Tresierra A \& Z Culquichicón. 1995. Manual de biología pesquera, $227 \mathrm{pp}$. Libertad, Trujillo.

Valdés DS \& E Real. 2004. Nitrogen and phosphorus in water and sediments at Ria Lagartos coastal lagoon, Yucatan, Gulf of Mexico. Indian Journal of Geo-Marine Sciences 33: 338345.

Van Rooij JM, E de Jong, F Vaandrager \& JJ Videler. 1996. Resource and habitat sharing by the stoplight parrotfish Sparisoma viridae a Caribbean reef herbivore. Environmental Biology of Fishes 47: 81-91.

Ward-Campbell BMS, FWH Beamish \& C Kongchaiya. 2005. Morphological characteristics in relation to diet in five coexisting Thai fish species. Journal of Fish Biology 67: 12661279.

Wootton RJ. 1998. Ecology of teleost fishes, 392 pp. Springer, London.

Yáñez-Arancibia A. 1975. Estudios de peces en las lagunas costeras: nota científica. Anales del Instituto de Ciencias del Mar y Limnología, UNAM 2: 53-60.

Zahorcsak P, RA Silvano \& I Sazima. 2000. Feeding biology of a guild of benthivorous fishes in a sandy shore on southeastern Brazilian coast. Revista Brasileira de Biologia 60: 511-518. 
Appendix 1. Food spectrum of $E$. argenteus (Ea) and $E$. gula (Eg) in the Ría Lagartos lagoon system, Yucatán. UOM: unidentified organic material and UAM: unidentified animal material / Espectro alimentario de E. argenteus (Ea) y E. gula (Eg) en el sistema lagunar de Ría Lagartos, Yucatán. UOM: material orgánico no identificado y UAM: material animal no identificado

\begin{tabular}{|c|c|c|c|c|c|c|c|}
\hline \multicolumn{2}{|c|}{ Taxonomic groups } & \multirow[t]{2}{*}{$\mathrm{Ea}$} & \multirow[t]{2}{*}{$\mathrm{Eg}$} & \multicolumn{2}{|c|}{ Taxonomic groups } & \multirow{2}{*}{$\frac{\mathrm{Ea}}{\mathrm{x}}$} & \multirow[t]{2}{*}{$\mathrm{Eg}$} \\
\hline Phytoplankton & & & & Polychaeta & 39. Onuphidae spp. & & \\
\hline Cyanophyceae & 1. Oscillatoria spp. & $\mathrm{x}$ & $\mathrm{x}$ & & 40. Nereidae spp. & $\mathrm{x}$ & $\mathrm{x}$ \\
\hline & 2. Cyanophita unident. & & $\mathrm{x}$ & & 41. Sabellydae spp. & $\mathrm{x}$ & \\
\hline \multirow[t]{13}{*}{ Diatoms } & 3. Biddulphia spp. & $\mathrm{x}$ & $\mathrm{x}$ & & 42. Syllidae spp. & $\mathrm{x}$ & $\mathrm{x}$ \\
\hline & 4. Cytatesima spp. & $\mathrm{x}$ & & & 43. Afroditidae spp & & $\mathrm{x}$ \\
\hline & 5. Amphora spp. & $\mathrm{x}$ & $\mathrm{x}$ & & 44. Spionidae spp. & & $\mathrm{x}$ \\
\hline & $\begin{array}{l}\text { 6. Grammatophora } \\
\text { spp. }\end{array}$ & $\mathrm{x}$ & $\mathrm{x}$ & & 45. Ampharetidae spp. & & $\mathrm{x}$ \\
\hline & 7. Gyrosigma spp. & $\mathrm{x}$ & $\mathrm{x}$ & & 46. Orbinidae spp. & & $\mathrm{x}$ \\
\hline & 8. Melosira spp. & $\mathrm{x}$ & $\mathrm{x}$ & & 47. Polychaete unident. & $\mathrm{x}$ & $\mathrm{x}$ \\
\hline & 9. Navicula spp. & $\mathrm{x}$ & $\mathrm{x}$ & Echiura & & & \\
\hline & 10. Nitzchia spp. & $\mathrm{x}$ & $\mathrm{x}$ & Echiuroidea & 48. Equiurid unident. & $\mathrm{x}$ & $\mathrm{x}$ \\
\hline & 11. Cymatosira spp. & & $\mathrm{x}$ & Crustacea & & & \\
\hline & 12. Fragillaria spp. & & $\mathrm{x}$ & Ostracoda & 49. Ostracods unident. & $\mathrm{x}$ & $\mathrm{x}$ \\
\hline & 13. Pinnularia spp. & & $\mathrm{x}$ & Copepoda & 50. Calanoida spp. & $\mathrm{x}$ & $\mathrm{x}$ \\
\hline & 14. Merismopedia spp & & $\mathrm{x}$ & & 51. Cyclopoida spp. & $\mathrm{x}$ & $\mathrm{x}$ \\
\hline & 15. Diatoms unident. & $\mathrm{x}$ & $\mathrm{x}$ & & 52. Harpacticoida spp. & $\mathrm{x}$ & $\mathrm{x}$ \\
\hline Macrophytes & & & & Amphipoda & 53. Aoridae spp. & $\mathrm{x}$ & $\mathrm{x}$ \\
\hline Algae & 16. Hypnea spp. & $\mathrm{x}$ & $\mathrm{x}$ & & 54. Corophiidae spp. & $\mathrm{x}$ & $\mathrm{x}$ \\
\hline Seagrass & 17. Halodule spp. & $\mathrm{x}$ & $\mathrm{x}$ & & 55. Gammaridae & $\mathrm{x}$ & $\mathrm{x}$ \\
\hline Protozoa & & & & & 56. Amphipods unident. & $\mathrm{x}$ & $\mathrm{x}$ \\
\hline Dinoflagellata & 18. Dinoflagellata & & $\mathrm{x}$ & Isopoda & 57. Sphaeroma spp. & $\mathrm{x}$ & $\mathrm{x}$ \\
\hline Ciliophora & 19. Ciliophora unident. & & $\mathrm{x}$ & & 58. Aega spp. & & $\mathrm{x}$ \\
\hline \multirow[t]{5}{*}{ Foraminifera } & 20. Anomalina spp. & $\mathrm{x}$ & $\mathrm{x}$ & & 59. Cassidinidea spp. & & $\mathrm{x}$ \\
\hline & 21. Bolivina spp. & $\mathrm{x}$ & $\mathrm{x}$ & & 60. Idotea spp. & & $\mathrm{x}$ \\
\hline & 22. Globigerina spp. & $\mathrm{x}$ & $\mathrm{x}$ & & 61. Isopods unident. & $\mathrm{x}$ & $\mathrm{x}$ \\
\hline & 23. Spiroculina spp. & $\mathrm{x}$ & $\mathrm{x}$ & Tanaidacea & 62. Leptucheila spp. & $\mathrm{x}$ & $\mathrm{x}$ \\
\hline & 24. Triloculina spp. & $\mathrm{x}$ & $\mathrm{x}$ & & 63. Paratanidae & $\mathrm{x}$ & $\mathrm{x}$ \\
\hline Mollusca & & & & & 64. Tanaidaceans unident. & $\mathrm{x}$ & $\mathrm{x}$ \\
\hline \multirow[t]{10}{*}{ Gastropoda } & 25. Barleeia spp. & $\mathrm{x}$ & & Cumacea & 65. Cumaceo unident. & $\mathrm{x}$ & $\mathrm{x}$ \\
\hline & 26. Bulla spp. & $\mathrm{x}$ & & Mysidacea & 66. Mysids unident. & $\mathrm{x}$ & $\mathrm{x}$ \\
\hline & 27. Crepidula spp. & $\mathrm{x}$ & $\mathrm{x}$ & Insecta & & & \\
\hline & 27. Hydrobiidae & $\mathrm{x}$ & & Diptera & 67. Diptera unident. & $\mathrm{x}$ & $\mathrm{x}$ \\
\hline & 28. Marginella spp. & $\mathrm{x}$ & & Hymenoptera & 68. Hymenoptera unident. & $\mathrm{x}$ & \\
\hline & 29. Tricolia spp. & $\mathrm{x}$ & & Coleoptera & 69. Coleoptera unident. & $\mathrm{x}$ & \\
\hline & 30. Alvania spp. & & $\mathrm{x}$ & Zoobenthos & 70. Eggs & $\mathrm{x}$ & $\mathrm{x}$ \\
\hline & 31. Haminoidea & & $\mathrm{x}$ & UOM & 71. UOM & $\mathrm{x}$ & $\mathrm{x}$ \\
\hline & 32. Scaphandridae & & $\mathrm{x}$ & & 72. UAM & $\mathrm{x}$ & $\mathrm{x}$ \\
\hline & 33. Gastropods unident. & $\mathrm{x}$ & $\mathrm{x}$ & Detritus & 73. Organic matter & $\mathrm{x}$ & $\mathrm{x}$ \\
\hline \multirow[t]{3}{*}{ Bivalvia } & 34. Chione spp. & $\mathrm{x}$ & & Others & 74. Sponge spicules & $\mathrm{x}$ & $\mathrm{x}$ \\
\hline & 35. Parastarte spp. & $\mathrm{x}$ & & & 75. Fish larvae & $\mathrm{x}$ & \\
\hline & 36. Bivalve unident. & $\mathrm{x}$ & $\mathrm{x}$ & & 76. Limulus polyphemus & $\mathrm{x}$ & \\
\hline Nematoda & 37. Nematode unident. & $\mathrm{x}$ & $\mathrm{x}$ & & 77. Seeds & & $\mathrm{x}$ \\
\hline Annelidae & & & & & 78. Pycnogonids & $\mathrm{x}$ & $\mathrm{x}$ \\
\hline Oligochaeta & 38. Arenicola spp. & $\mathrm{x}$ & $\mathrm{x}$ & & & & \\
\hline
\end{tabular}


Appendix 2. Trophic spectrum of E. argenteus (Ea) and E. gula (Eg) in Ría Lagartos lagoon system, Yucatán, expressed in terms of relative percentage of abundance (A), weight (W), frequency of occurrence (FO) and Relative Importance Index (RII) of the taxonomic groups. UOM: unidentified organic material / Espectro trófico de E. argenteus (Ea) y E. gula (Eg) en el sistema lagunar de Ría Lagartos, Yucatán, expresado en términos de abundancia relativa (A), peso (W), frecuencia de ocurrencia (FO) e Indice de Importancia Relativa (RII) de los grupos taxonómicos. UOM: material organico no identificado

\begin{tabular}{|c|c|c|c|c|c|c|c|c|}
\hline \multirow{2}{*}{ Taxonomic group } & \multicolumn{2}{|c|}{ A } & \multicolumn{2}{|c|}{$\mathrm{W}$} & \multicolumn{2}{|c|}{ FO } & \multicolumn{2}{|c|}{ RII } \\
\hline & $\mathrm{Ea}$ & $\mathrm{Eg}$ & $\mathrm{Ea}$ & $\mathrm{Eg}$ & $\mathrm{Ea}$ & $\mathrm{Eg}$ & $\mathrm{Ea}$ & $\mathrm{Eg}$ \\
\hline \multicolumn{9}{|l|}{ Phytoplankton } \\
\hline Cyanophyceae & 0.11 & 0.93 & 0.11 & 0.69 & 3.04 & 7.96 & 0.01 & 0.13 \\
\hline Diatoms & 0.5 & 0.82 & 0.54 & 0.62 & 12.17 & 20.37 & 0.15 & 0.3 \\
\hline \multicolumn{9}{|l|}{ Macrophyta } \\
\hline Seagrasses & 1.24 & 2.27 & 1.62 & 1.88 & 16.02 & 37 & 0.58 & 1.58 \\
\hline \multicolumn{9}{|l|}{ Protozoa } \\
\hline Foraminifera & 1.98 & 2.15 & 2.08 & 2.04 & 26.77 & 34.89 & 1.22 & 1.5 \\
\hline \multicolumn{9}{|l|}{ Nematoda } \\
\hline Nematodes & 0.96 & 1.19 & 0.75 & 1.3 & 23.53 & 20.84 & 0.39 & 0.53 \\
\hline \multicolumn{9}{|l|}{ Annelidae } \\
\hline Polychaeta & 16.04 & 27.52 & 23.11 & 32.82 & 57 & 72.6 & 28.12 & 45.03 \\
\hline \multicolumn{9}{|l|}{ Echiuridae } \\
\hline Echiurids & 0.59 & 2.79 & 2.61 & 2.67 & 1.42 & 9.6 & 0.09 & 0.54 \\
\hline \multicolumn{9}{|l|}{ Mollusca } \\
\hline Bivalvia & 0.55 & 2.51 & 0.82 & 2.4 & 6.9 & 15.69 & 0.13 & 0.79 \\
\hline Gastropoda & 1.06 & 0.38 & 1.13 & 0.29 & 5.88 & 6.09 & 0.16 & 0.04 \\
\hline \multicolumn{9}{|l|}{ Crustacea } \\
\hline Amphipoda & 22.56 & 16.23 & 26.76 & 16.03 & 58.22 & 42.86 & 33.33 & 14.21 \\
\hline Copepoda & 5.15 & 6.45 & 5.23 & 6.11 & 50.71 & 54.57 & 5.7 & 7.05 \\
\hline Ostracoda & 1.69 & 2.33 & 1.56 & 2.54 & 29.82 & 31.38 & 1.02 & 1.57 \\
\hline Cumacea & 0.12 & 0.08 & 0.11 & 0.07 & 1.22 & 1.64 & 0.01 & 0 \\
\hline Mysidacea & 0.3 & 0.68 & 0.33 & 0.43 & 2.64 & 3.04 & 0.02 & 0.03 \\
\hline Isopoda & 0.07 & 0.78 & 0.08 & 1.95 & 1.62 & 4.68 & 0 & 0.13 \\
\hline Tanaidacea & 10.18 & 12.73 & 10.28 & 10.15 & 42.6 & 36.3 & 9.45 & 8.54 \\
\hline \multicolumn{9}{|l|}{ Insecta } \\
\hline Insects & 3.14 & 0.04 & 1.89 & 0.02 & 7.51 & 0.23 & 0.36 & 0 \\
\hline \multicolumn{9}{|l|}{ Detritus } \\
\hline Detritus & 25.62 & 11.68 & 13.21 & 10.37 & 42.8 & 50.12 & 12.46 & 11.36 \\
\hline \multicolumn{9}{|l|}{ UOM } \\
\hline UOM & 7.74 & 7.76 & 7.41 & 7.06 & 42.19 & 43.56 & 6.76 & 6.63 \\
\hline \multicolumn{9}{|l|}{ Zoobenthos } \\
\hline Zoobenthos & 0.1 & 0.14 & 0.12 & 0.1 & 1.62 & 1.17 & 0.01 & 0 \\
\hline \multicolumn{9}{|l|}{ Others } \\
\hline Others & 0.3 & 0.55 & 0.26 & 0.47 & 4.06 & 5.15 & 0.03 & 0.02 \\
\hline
\end{tabular}

